\title{
Factors Affecting Kenya Alpine Dairy Goat Milk Production in Nyeri Region
}

\author{
Mburu Monica $^{1}$, Mugendi Beatrice ${ }^{1}$, Makhoka Anselimo ${ }^{2} \&$ Muhoho Simon ${ }^{2}$ \\ ${ }^{1}$ Institute of Food Bioresource Technology, Dedan Kimathi University of Technology, Kenya \\ ${ }^{2}$ Department of Food Science and Technology, Jomo Kenyatta University of Agriculture and Technology, \\ Kenya \\ Correspondence: Mburu Monica, Institute of Food Bioresource Technology, Dedan Kimathi University of \\ Technology, P O Box 657-10100 Nyeri, Kenya. Tel: 254-714-915-397. E-mail: monica.mburu@dkut.ac.ke
}

Received: June 9, 2014 Accepted: September 28, 2014 Online Published: October 7, 2014

doi:10.5539/jfr.v3n6p160 URL: http://dx.doi.org/10.5539/jfr.v3n6p160

\begin{abstract}
In Kenya use of exotic dairy goats in breeding programmes for smallholder production systems has become popular, but information on the milk production is scarce. A study was carried out to assess the milk yield of dairy goats reared in high potential and semi arid areas of Nyeri County. This involved 190 smallholder farmers rearing Alpine dairy goats in Nyeri County and registered with Dairy Goat association of Kenya (DGAK), which formed $100 \%$ sampling of the population under study. The grade, feeding practices and age of the dairy goats were evaluated. The appendix grade in Kieni East gave the highest milk production of 2.69 liters per day, while the foundation grade in Mukurweini gave the lowest milk production of 0.98 litres per day. The higher milk production in Kieni East, a semi arid area, was due to good feeding practices, where $43 \%$ of the farmers used concentrates during milking and $48 \%$ supplemented the feed with minerals. In the high potential area of Mukurweini none of the farmers used mineral supplements with only $13 \%$ using concentrates during milking. The age of the dam was evaluated for the pedigree grade, where it significantly affected the average milk production. At the age of 5.0 to 5.9 years, the pedigree grade in Kieni East and Mukurweini gave highest production of 2.84 and 2.96 liters per day respectively. The results demonstrated that poor feeding practices, dam age and grade, significantly $(\mathrm{p} \leq 0.05)$ affected the Alpine dairy goat milk production.
\end{abstract}

Keywords: dairy goat, milk production, dam age, dam grade, feeding

\section{Introduction}

Dairy goats have become increasingly popular among development agencies that target the resource poor smallholder farmers in mixed crop-livestock production systems in the Eastern African highlands where farm sizes are small, and crop yields are low(Peacock, 2005). Goats form an integral component of the livestock enterprise in Kenya with an estimated population of 10.7 million (GOK, 2002) and spread in all agro-ecological zones of Kenya. In Kenya, through the combined efforts of the government and Non Governmental Organizations (NGO), the population of crossbred dairy goats have tremendously increased from less than 20,000 in 1991, to over 160,000 in 2005 (FARM-Africa, 1997). Goat improvement programmes, when well planned and executed, offer great opportunities for improvements of livelihoods of some of the poorest farmers in developing countries (Okeyo et al., 1999; Peacock, 2005). These goats can play a significant role in improving the livelihoods of poor smallholders in these areas. Their small size and early maturity makes them especially suitable for use as a first step towards wealth creation. Dairy goat improvement strategies have mainly been crossbreeding of indigenous goats with exotic dairy types, resulting in crossbred populations with varying levels of exotic genes (Bradford, 1981; Ruvuna et al., 1988; Das et al., 1996). Goats are reared to provide meat, milk, hides and manure, and are easy to keep and feed (Nyendwa, 2002). The Alpine breeds have been identified to be a cross breed between the German Alpine and Kenyan Alpine (Kipserem et al., 2011). Interest in the value of goats as domestic livestock is presently widespread in the region. Its importance has been identified by the wide recognition of their role in food production as well as other economic importance in the tropics and sub-tropics where they are concentrated forming an important component of traditional farming systems. Kinyanjui et al. (2008) studied the socio-economic issues of the dairy goat in Kenya and revealed that about $57 \%$ of the milk produced was consumed in the household. Thus, dairy goats enable households to access milk especially for the 
children and the old. Surplus milk is sold despite the little amount of goat milk produced. Kinyanjui et al. (2008) also able to establish that the farm gate prices for the milk ranged from Kenya Shillings 120.00 to 150.00 per liter in hospitals, hotels, church congregation and dairy processors who purchase goat milk for making cheese.

Kenya Alpine dairy goats usually live in the Central and Eastern highlands of Nyeri and Meru Districts respectively, but in recent years they have spread to other areas of lower potential compared to the original entry areas. These areas are characterized by a humid to sub-humid climate with long, wet and cold wet seasons. Herds are usually zero grazed and stall fed on greens and very little or no concentrate supplementation is provided. Water is also provided in the shed. The kidding season is usually not synchronized but rather depends on conditions of pasture. Nyeri district is an agriculturally high potential district with plenty of rainfall, with 51 percent of the district being semi-arid (Price Water House Coopers, 2005). The semi arid areas are Kieni East and Kieni West, which are characterized by low primary vegetation productivity and high geographical and seasonal variability in water availability.

The local dairy goat cross breeding with exotic breed is carried out as indicated in Figure 1. The dairy goats are bred for milk production and are expected to produce up to 3 times that of the local goats. They multiply fast, kidding twice a year often producing twins or triplets. The milk quality of crossbred grades is also expected to be better than the local goats. The farmers under study had been trained on the breeding pattern and supplied with the German Alpine bucks for breeding purposes. The breeding trend is slowly being lost due to lack of information to the farmers on the benefits of dairy goat farming and shortage of agricultural extension officers to ensure follow up.

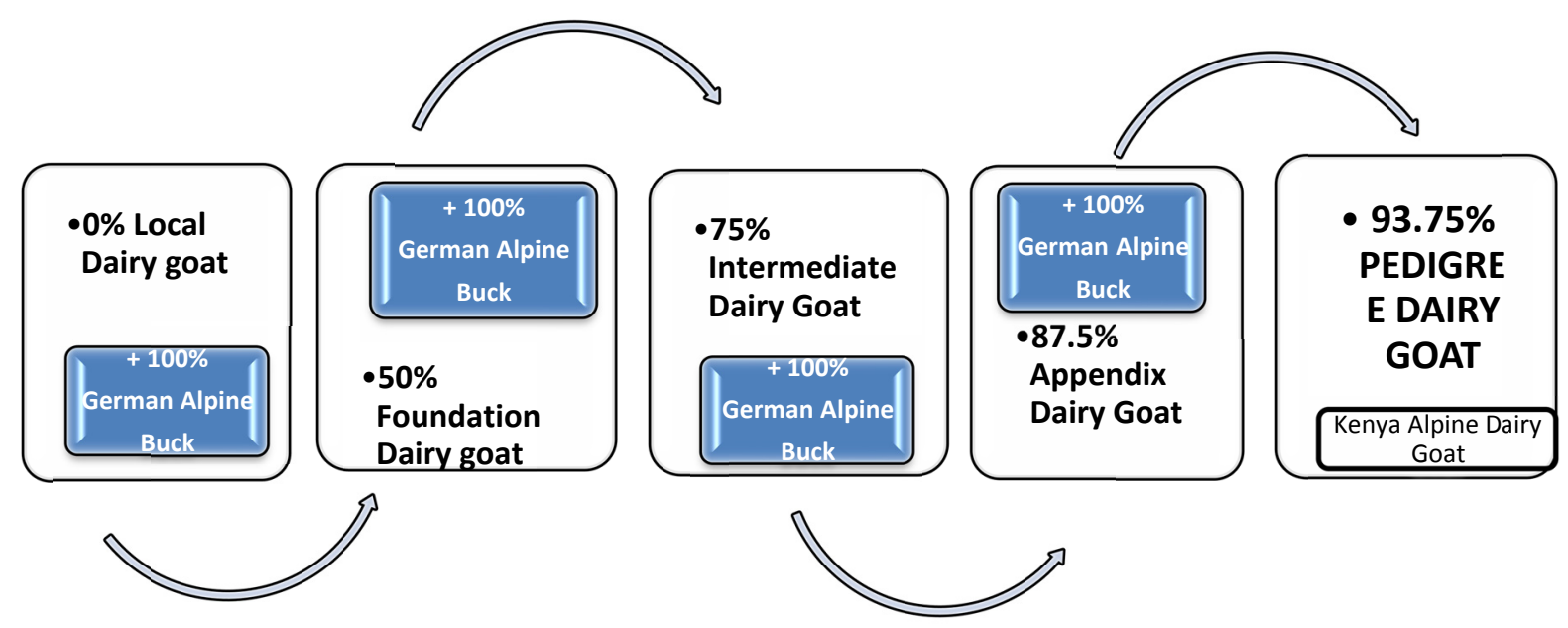

Figure 1. Diary goat breeding plan

The Dairy Goat Association of Kenya (DGAK) has been promoting dairy goat keeping with various groups of small scale farmers in Nyeri County, but there are no studies taken to assess the implication of this project, including documented management practices and effect of the dairy goat crossbreeding programme on the milk yield and quality. There is need to identify constraints, and opportunities for guidance and targeting of expansion of the dairy goat multiplication and how the programme can be improved, for income generation in Kenya. Policy recommendations towards better milk yields by the dairy goats and improved management practices aimed at cheaper and effectively utilized inputs may be a priority for the dairy goat industry.

The study was carried out to evaluate how the quantity and quality of dairy goats' milk is affected by the age of the dam, grade, feeding, and geographical location of the goat rearing. This was achieved through investigating the productivity of dairy goats reared in Nyeri County in two different geographical regions; Mukurweini representing high potential area and Kieni East and West representing semi arid area. The findings from this study will form the basis for dairy goat improvement across the board and value addition through locally adaptable technology that can be used to enhance the income of the poor farmers and enhance poverty eradication at village level. 


\section{Materials and Methods}

\subsection{Study Site}

The study identified stakeholders as the different farmer groups and the Dairy Goat Association of Kenya (DGAK). In collaboration with these stakeholders, a baseline survey was conducted with farmer groups in the high potential and semi arid areas in Nyeri county, which included - high potential areas; Mukurweini and, semi arid areas; Kieni east and Kieni West. It comprised $100 \%$ of the population, who are farmers registered with the DGAK and have undergone adequate training in dairy goat keeping, practicing good husbandry and producing enough milk. These areas were selected with the help of the DGAK Director who indicated potential farmers where the researcher could obtain adequate and accurate data. With the help of DGAK Assistants in these areas, the researcher was able to select farmers with productive registered dairy goats.

\subsection{Data Description}

The study adopted a descriptive survey method that used both secondary and primary data to generate the information required. The primary data was collected through an in depth face to face interview after developing a research questionnaire. This questionnaire comprised of closed and open ended questions and it incorporated issues raised in the problem statement. Participant observation was also used. Besides, secondary data on dairy goat entrepreneurs was obtained from existing sources that were available at the DGAK, reviewed journals and books. Use of search engines also supplemented these sources. Two-group simple randomized design was applied, by defining the population first and then from the population a sample was selected randomly, for the baseline survey.

The data was analyzed using the Statistical Package for Social Scientists (SPSS) software.

\subsection{Data Analysis}

Analyses of variance were conducted using generalised linear models (GLM) of SPSS version 18 (SPSS, 2009) for dam grade, dam age and milk production in order to assess their effect per region under study.

\section{Results}

\subsection{Dairy Goat Feeding Practices}

Data on dairy goat feeding for the study area is presented in Table 1 . All the farmers fed the dairy goats with natural pastures which include weeds, shrubs; banana leaves, potato peels, fodder crops like nappier grass, maize stalks, sweet potato vines, green leafy twigs. They mainly used available plant material found on the farm. Only few farmers supplemented the feed with concentrates, a fact that contributed to the lower milk production by the dairy goats, which is in agreement with findings of Ogola et al. (2010).

Table 1: Dairy goat feeding practices

\begin{tabular}{llll}
\hline Type of Feeding & Kieni East & Kieni West & Mukurweini \\
\hline Normal Pasture & $100 \%$ & $100 \%$ & $100 \%$ \\
Normal Pasture + Concentrates & $43 \%$ & $5 \%$ & $13 \%$ \\
Normal Pasture + Mineral supplements & $48 \%$ & $32 \%$ & $0 \%$ \\
Total Respondents & 78 & 73 & 39 \\
\hline
\end{tabular}

\subsection{Effect of Age on Pedigree Dairy Goat Milk Production}

The Effect of dam age for the pedigree gade was evaluated in the study areas as presented in Figure 2. 


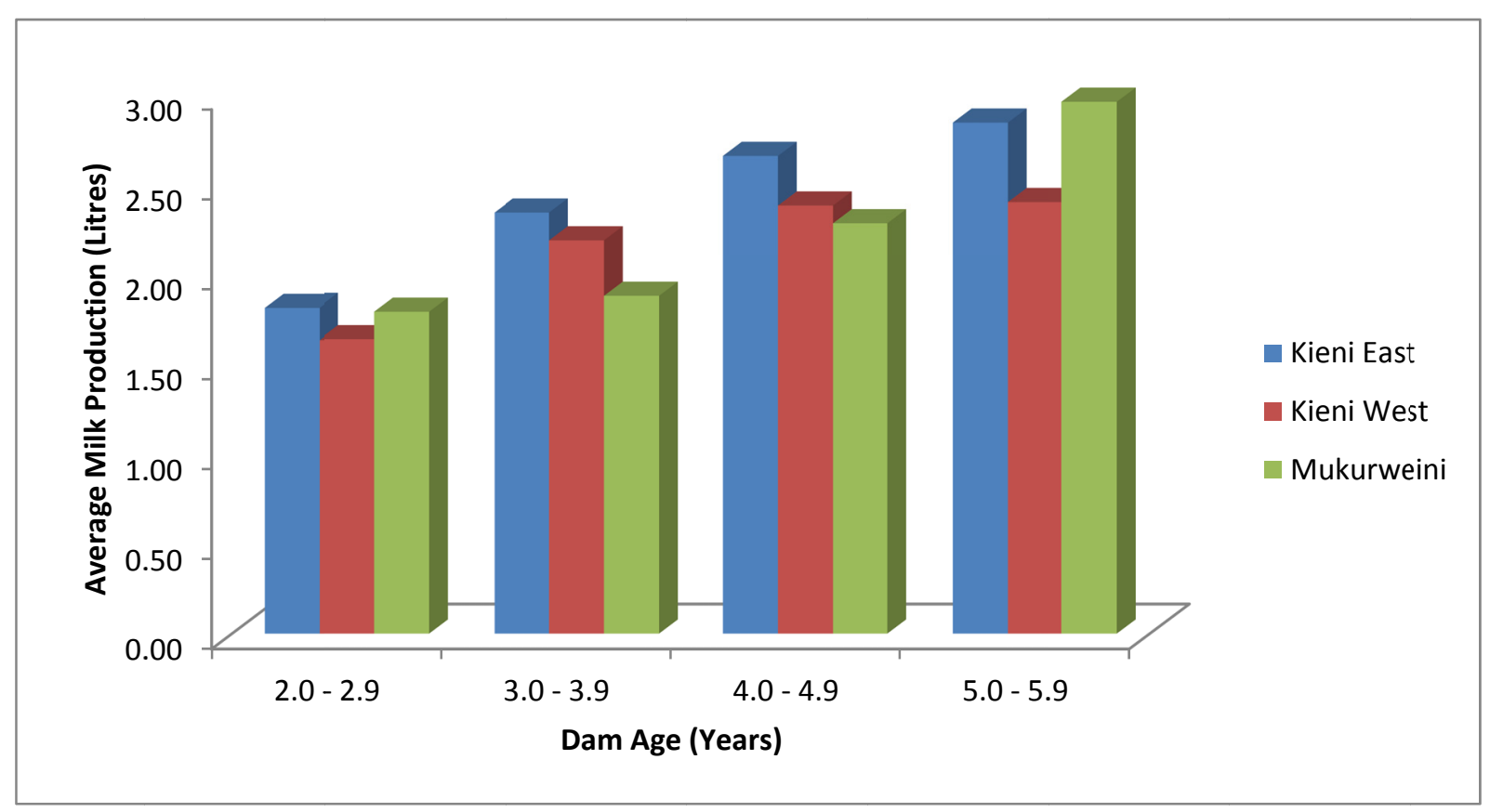

Figure 2. Effect of pedigree dam age on daily milk production per region $(p \leq 0.05)$

The pedigree dam starts to produce milk at the age of 2 years. The average milk production between the ages of 2 to 2.9 years is not significantly different $(\mathrm{p} \leq 0.05)$, for the three regions.

There is a significance increase in milk production at the age of 5.0 to 5.9 years for both Kieni East and Mukurweini, giving 2.84 and 2.96 liters per day respectively.

\subsection{Effect of Dam Grade on Dairy Goat Milk Production}

Using the General Linear Model (GLM) Univariate to perform a two-factor analysis of variance, the effect of grade per region on daily milk production was evaluated as presented in Table 2.

The pedigree grade in Mukurweini gave the highest milk production of 2.31 litres while the foundation grade yielded the lowest of 0.98 litres per day, in the same region. The low milk production in Mukurweini could have been due to low concentrates given to the dairy goats in this region. In Kieni East the pedigree grade produced 2.07 litres, while the appendix grade gave 2.69 litres in this region. In Kieni West the pedigre grade gave the highest milk production of 2.15 litres as compared with the other grades in the same region. The pedigree grade in Mukurweini and Kieni West did best, while the appendix in Kieni East gave the best results. The pedigre grade being an improvement of the local goats is expected to yield more milk per day in all the regions. 
Table 2. Effect of Dam grade per region on average dairy goat milk production

\begin{tabular}{lllll}
\hline Region & Dam Grade & Average Daily Milk Production & Std. Deviation & $\mathrm{N}$ \\
\hline Kieni East & Local & 2.28 & 0.94 & 18 \\
& Foundation & 1.25 & 0.35 & 11 \\
& Intermediate & 2.04 & 0.70 & 8 \\
& Appendix & 2.69 & 0.35 & 17 \\
& Pedigree & 2.07 & 0.75 & 25 \\
\hline Kieni West & Local & 1.00 & 0.00 & 2 \\
& Foundation & 1.53 & 0.47 & 9 \\
& Intermediate & 1.81 & 0.77 & 17 \\
& Appendix & 1.77 & 0.40 & 20 \\
& Pedigree & 2.15 & 0.62 & 25 \\
\hline Mukurweini & Local & 1.33 & 0.40 & 5 \\
& Foundation & 0.98 & 0.17 & 5 \\
& Intermediate & 1.08 & 0.25 & 4 \\
& Appendix & 1.34 & 0.39 & 9 \\
\hline
\end{tabular}

The variations were evaluated further using a plot as presented in Figure 3.

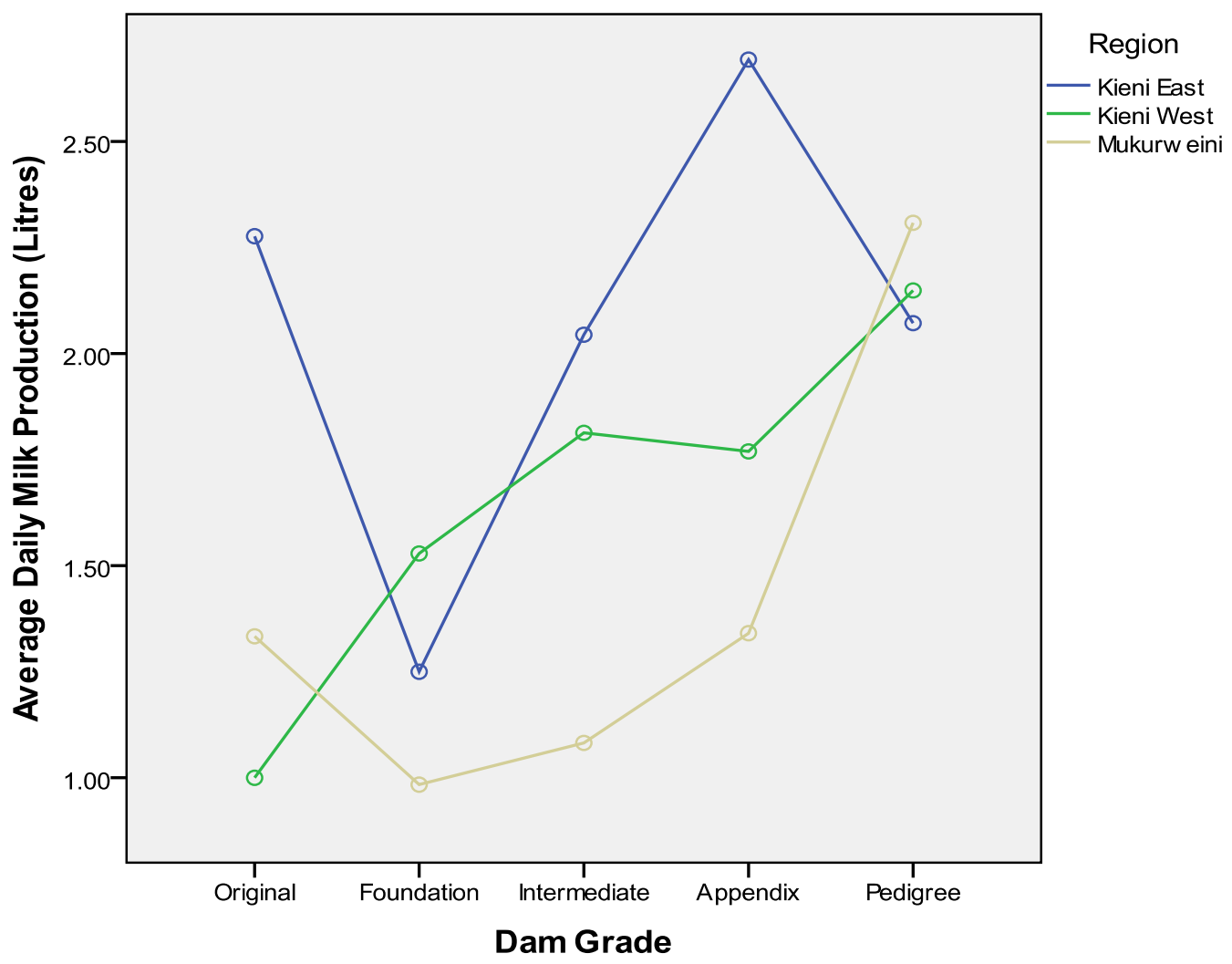

Figure 3. Effect of crossbreeding on daily milk production

The plot indicate interaction effect between the dam grade in each region. The difference in milk production for all the grades is greater for dairy goats in Mukurweini region as compared to the other two regions. The 
appendix grade in Kieni East gives the highest milk production of 2.69 litres per day. This being a semi arid area the high milk production could be attributed by the good feeding programme as demonstrated in Table 1 .

Table 3. Analysis of variance for effect of dam grade and region on daily milk production

\begin{tabular}{lllllll}
\hline Source & Type III Sum of Squares & df & Mean Square & F & Sig. & Partial Eta Squared \\
\hline Corrected Model & $38.34^{\mathrm{a}}$ & 14 & 2.74 & 5.198 & 0.000 & 0.294 \\
Intercept & 335.86 & 1 & 335.86 & 637.620 & 0.000 & 0.785 \\
Region & 10.122 & 2 & 5.06 & 9.608 & 0.000 & 0.099 \\
DamGrade & 15.33 & 4 & 3.83 & 7.277 & 0.000 & 0.143 \\
Region * DamGrade & 14.54 & 8 & 1.81 & 3.450 & 0.001 & 0.136 \\
Error & 92.18 & 175 & 0.52 & & & \\
Total & 816.94 & 190 & & & \\
Corrected Total & 130.51 & 189 & & &
\end{tabular}

a. R Squared $=.294$ (Adjusted R Squared $=.237$ ).

The significance value of the $\mathrm{F}$ test in the ANOVA table is 0.001 , an indication that the dairy goat milk production for different grades is significantly different for each region under study. However the $\mathrm{R}$ square shows a weak relationship of $29 \%$ among the different regions and grades.

\section{Discussion}

All the respondents in the three study areas used normal pasture to feed the dairy goats, which comprised of grass, shrubs, sweet potato vines, weeds in the farm. The dairy goats are normally tethered in the homestead for the better part of the day. $43 \%$ of farmers in Kieni East used concentrates mainly during milking to calm down the goat, while Kieni West had only 5\%, due to financial constraints. In Mukurweini $13 \%$ of the farmers used concentrates during milking. As for the mineral supplements, Kieni East and Kieni West rated 48\% and 32\% respectively. Farmers in Mukurweini did not do supplementation because being a high potential area the goat is fed with high nutrient fodders that are known to contain adequate nutrients. There materials include calliandra and other green soft shrubs which they use to feed the goats and find it sufficient to supply the necessary nutrients. There is a need to educate the farmers on efficient utilization of the feed available to achieve maximum returns. Feed supplementation with concentrates and mineral supplements was higher in Kieni East than the other two areas, a factor that contributes to higher milk production.

On overall, the adequacy and timeliness of feeding management was found to be the factors that mainly contributed to low milk production. These was agreement with findings of Ogola et al. (2010). Generally, proper feeding would enhance production of the dairy goats and, consequently, better milk yields which can enable farmers to cater for their household needs as well as for enterprise.

The pedigree grade did well in the three regions with Kieni East giving 2.07 litres, Kieni West 2.15 litres and Mukurweini 2.31 litres. Milk production for each grade varied per region, with the underlying reason being poor feeding practices and loss of interest by the farmers on dairy goat keeping especially in Mukurweini. All the respondents indicated that the dairy goat project which is spearheaded by DGAK, is not giving them much expected benefits due to lack of market for the milk, lack of concentrates to supplement the feeds due to low farmers income, lack of pastures and abandonment of the breeding system. It was noted that these effects are highly felt in Mukurweini, Nyeri area, where many farmers have sold the dairy goats and opted for dairy cow keeping. But this is only feasible for households with farms large enough to produce enough fodder for the dairy cows, therefore dairy goat keeping remains viable if these effects could be addressed.

The 190 small holder farmers interviewed revealed that there is no dairy goat milk processor in the entire study area. Local markets for dairy goat milk do exist, where the respondents revealed that they sell their milk to special demand from specific individuals mainly suffering from ailments such as diabetes, AIDS and those sensitive to cow milk. During the study it was noted that many farmers have neglected dairy goat farming due to lack of market for the milk as well as donors withdrawal.

The dam starts to produce milk at the age of 2.0 to 2.9 years, for the pedigree grade, with no significant 
difference $(\mathrm{p} \leq 0.05)$ in the three regions. There is a noted increase in milk production for the pedigree grade at the age of 5.0 and 5.9 years, in the three regions. At this age the dams are kidding less, giving more milk for household use.

The study established that the average daily milk production of the dairy goat is mainly affected by the dam grade as well as feeding program. Proper improvement of the breeding, through record keeping and follow up can lead to superior pedigree grades with higher milk production. Due to lack of concentrates and mineral supplements, the farmers should utilize plant material already available on the farm such as napier grass, herbaceous and shrub legumes, plants rich in nitrogenous matter like forage legumes and calliandra, among others, inorder to achieve high milk yields. Increasing milk production at lower costs will not only improve the nutritional status of resource-poor communities but will also improve the incomes of smallholder dairy farmers. To produce adequate milk, a dairy goat requires a well-balanced diet for both self-maintenance and production of milk (Kamau et al., 2008).

Despite the increasing demand for dairy goats due to diminishing land sizes, production is growing very slowly due to poor breeding and management practices by small-scale farmers. The Dairy Goat Association of Kenya that regulates production, train farmers and set standards for improving the quality of dairy goats, is faced by inadequate funds that lead to low field interventions. Many farmers and brokers have taken advantage of this to sell low quality dairy goats claiming they are pure breeds. The respondents in this study stated that the dairy goat sub-sector cannot grow unless urgent measures are taken to reduce inbreeding and poor management.

The Kenya Alpine daily goats used in this study had been cress bred with German Alpine buck. The farmers involved in this project highlighted that introduction of exotic dairy goats brought hope to the dairy goat farming with some expecting high milk yield as much as 6 litres per a day. Lack of breeding stock and cheating by farmers is destroying the dairy goat industry. The import ban on all life animals in Kenya has caused a major lack of pure pedigree bucks to purify the breeding system.

\section{Conclusion}

The study has established that dairy goat milk production is affected by the age of the dam, the grade (breeding), and feeding practices. Small-scale farmers can operate a successful and therefore sustainable dairy goat production, with proper breeding and feeding especially by use of supplements and concentrates, that can yield sufficient milk for household consumption as well as for enterprise. However the breeding sequence has to be enhanced for the project to succeed.

\section{Acknowledgments}

I wish to acknowledge DAAD Kenya for the In-country scholarship offered for this study.

\section{References}

Bradford, G. E. (1981). Potential of dairy goats as a source of milk on smallholder farms in Kenya.In Proceedings of the Animal Production Society of Kenya, pp. 48-54.

Das, S. M., Rege, J. E. O., \& Mesfin, S. (1996). Phenotypic and genetic parameters of growth traits of blended goats at Malya, Tanzania. In Third Biennial Conference of the African Small Ruminant Research Network UICC, Kampala, Uganda, pp. 63-70

FARM-Africa. (1997). Project reports, FARM-Africa Kenya Country Office, Nairobi.

Government of Kenya (GOK).(2002). Ministry of Livestock Annual report, Government printer press, Nairobi.

Kamau, F., Nkonge, P., Sigilai, S., Mwangi, J., Mwangangi, S., Yoongo, D., ... Gikonyo, M. (2008). Livestock Production Extension Manual (3rd ed.) Nairobi: The Ministry of Livestock Development.

Kinyanjui, A., Murage, A., \& Mbugua, D. (2008). Socio-Economic Effects of Dairy Goat Production in Kenya. Retrieved October 10, 2011, from http://www.kari.org/fileadmin/publications/10thproceedings/Volone/SocioEconomicEffect.pdf

Kipserem, J., Sulo, T., Chepng'eno, W., \& Korir, M. (2011). Analysis of factors affecting dairy goat farming in Keiyo North and Keiyo South Districts of Kenya. Journal of Development and Agricultural Economics, $3(11), 555-560$.

Nyendwa, S. (2002). “Go For Goats!'.African Farming and Food Processin. Article September-October, 15, Nairobi.

Ogola, T. D. O., Nguyo, W. K., \& Kosgey, I, S. (2010). Dairy goat production practices in Kenya: Implications for a breeding programme. Livestock Research for Rural Development, 22(1). 
Okeyo, A. M., Ahuya, C. O., \& Wanyoike, M. M. (1999). Carcass tissue distribution and characteristics of small East African and Galla goats, and their F1 crosses to Toggenburg and Anglo-Nubian. Ind. J. Anim. Sci., 71, 868-871.

Peacock, C. (2005). Goats a pathway out of poverty. Small Rumin. Res. 60, $179-186$. http://dx.doi.org/10.1016/j.smallrumres.2005.06.011

Price Water House Coopers. (2005). Nyeri District (Kieni) Vision and Strategy: 2005-2015.

Ruvuna, F., Cartwright, T.C., Blackburn, H., Okeyo, M., \& Chema, S. (1988). Lactation performance of goats and growth rates of kid under different milking and rearing methods in Kenya. Anim. Prod, 46, $237-242$. http://dx.doi.org/10.1017/S000335610004229X

SPSS. (2009). PASW statistics 18, July 30, 2009.

\section{Copyrights}

Copyright for this article is retained by the author(s), with first publication rights granted to the journal.

This is an open-access article distributed under the terms and conditions of the Creative Commons Attribution license (http://creativecommons.org/licenses/by/3.0/). 